\title{
Collaborative Governance: The Opportunity in Policy Advocacy of Continuum of Care to Improving Indonesian Women's and Children's Health
}

\author{
Edi Mulyanto ${ }^{1}$, Endang Larasati ${ }^{2}$, Kismartini $^{3}$, Ika Riswanti Putranti ${ }^{4}$, Chriswardani \\ Suryawati $^{5}$ \\ \{edimulyanto143@gmail.com ${ }^{1}$ \} \\ Universitas Diponegoro, Indonesia ${ }^{1,2,3,4,5}$
}

\begin{abstract}
The World Health Organization states The Continuum of Care concept is the best approach to improving women's and children's health. Sustainable Development Goals (SDGs) commitment 2015-2030, mandates to reduce maternal, neonatal and under-five mortality. Collaborative governance is a governing arrangement where one or more public agencies directly engage non-state stakeholders in a collective decision-making process that is formal, consensus-oriented, and deliberative and that aims to make or implement public policy or manage public programs or assets. The aim of this paper is to explain how the Collaborative governance considered as adaptive management to ensure the implementation and sustainability in policy advocacy of Continuum of Care for improving Indonesian women's and children's health. There is an opportunity to apply this approach between stakeholders involved, on five elements (Penta Helix) model (consist of government, business, academia, civil society and media), in reducing maternal, neonatal and under-five mortality.
\end{abstract}

Keywords: Collaborative Governance, Advocacy, Continuum of Care Policy, Women's, Children's Health Services

\section{Introduction}

The Continuum of Care concept is now agreed to be the best approach to improving women's and children's health [1]. The Maternal Mortality Rate (MMR), Infant Mortality Rate (IMR), Neonatal Mortality Rate (NMR), and Under-five Mortality Rate (U5MR) are the indicators of health status. The Indonesian Ministry of Health adapt Continuum of Care concept in women and children health services [2]. The aim of this paper is to explain how the Collaborative governance considered as adaptive management to ensure the implementation and sustainability in policy advocacy of Continuum of Care in improving Indonesian women's and children's health to reduce neonatal, infant and under-five mortality. 


\section{Maternal, Neonatal, Infant and Under-five Mortality Situations in Indonesia}

\subsection{Maternal Mortality Situations}

There are three factors that influence the incidence of maternal death [3]:

a) Complications that occur in pregnancy, childbirth and the puerperium (obstetric complications).

b) Intermediate determinants, namely maternal health status, reproductive status, access to health services, health care behavior/use of health services and other unknown or unexpected factors.

c) Distant determinant; includes socio-cultural factors and economic factors.

WHO (2019) stated that the main complications in nearly $75 \%$ of all maternal deaths are due to: heavy bleeding (mostly bleeding after delivery), infection (usually after delivery), high blood pressure during pregnancy (pre-eclampsia and eclampsia), complications from referral, and unsafe abortion? The others are caused by or related to infections or chronic conditions [4].

The Millennium Developments Goals (MDGs) mandates countries to improve maternal health [5]. Cases of maternal mortality in Indonesia are still at the position of 305 per 100,000 births, while the target set by the United Nations (UN) is 102 per 100,000 births, so that Indonesia is one of the countries with a relatively high MMR in ASEAN [5][6]. The achievement of reducing maternal mortality in Indonesia in 2015 is only better than Laos [6]. Development of regulations and maternal health policies, continues in the commitment of the Sustainable Development Goals (SDGs) 2015-2030, with the target by 2030 being the MMR to less than 70 per 100,000 births [5].

About $77 \%$ of maternal deaths in Indonesia occur in hospitals, $15.6 \%$ in health centers, $4.1 \%$ on the way to health facilities, and the rest in other places [7].

\subsection{Neonatal, Infant, Under-five Mortality Situations}

Globally, in 2018, 4.0 million infant death (75\% of all under-five deaths) occurred within the first year of life. Annual infant deaths have declined from 8.8 million in 1990 to 4.0 million in 2018 [8]. Goal 5 of the MDGs mandates countries to improve infant health. IMR in Indonesia in 2015 was only better than Laos, Cambodia and Myanmar, and almost the same as the Philippines [6].

The development of health regulations and policies for infants, continued in SDGs commitment 2015-2030, mandates to reduce neonatal mortality to at least less than 12 per 1000 births and under-five mortality to as low as 25 per 1000 births. Data from the Ministry of Health in 2016, found that neonatal deaths due to complications from intrapartum events were $28.3 \%$, respiratory and cardiovascular disorders $21.3 \%$, prematurity and low birth $19 \%$, congenital abnormalities $14.8 \%$, infections (including tetanus in neonatal) $8.5 \%$ and other causes $8 \%$. Neonatal mortality in 2014 in Indonesia: 68\% occurred in hospitals, $13 \%$ in other health facilities; $16 \%$ at home, $2 \%$ on the way to health facilities, and the remaining $1 \%$ elsewhere [7]. Profile of neonatal, infant and under-five mortality rates base on Indonesian Demographic and Health Survey (Survey Demography dan Kesehatan Indonesia/SDKI) and target in 2024 and SDGs are shown in the table 1. 
Table 1. Profile and Target of Neonatal, Infant and Under-five Mortality Rates in Indonesia

\begin{tabular}{|c|l|c|c|c|}
\hline No. & Classification & SDKI 2017 & Target 2024 & SDGs 2030 \\
\hline 1 & Neonatal & $15(72.000)$ & 11.1 & 8.6 \\
\hline 2 & Infant & $24(151.000)$ & 16.8 & 12.3 \\
\hline 3 & Under-five & $32(153.600)$ & 16.8 & 12.3 \\
\hline \multicolumn{2}{|r|}{ Source: Indonesian Ministry of Health [7] } \\
\hline
\end{tabular}

Source: Indonesian Ministry of Health [7].

The Indonesian Academy of Sciences/Akademi Ilmu Pengetahuan Indonesia (AIPI), with its Evidence Summit (2018) program, states that the factors that trigger the high mortality rate for mothers and newborns are: quality of service, referral system, national health insurance, local government policies, culture, and early marriage [9].

\section{Continuum of Care Policy in Indonesia}

Indonesian regulations explain that maternal health efforts must be aimed at maintaining maternal health so as to be able to give birth to a healthy and quality generation and to reduce maternal mortality. Efforts to care for the infant and children health must be aimed at preparing healthy, smart, and quality future generations and to reduce IMR [10]. Decentralization of the health sector provides opportunities for local governments to innovate services and make health development programs more specific and according to needs.

The Indonesian Ministry of Health stated that the policy of reducing maternal mortality, neonatal mortality, infant mortality and under-five mortality is an interrelated and sustainable effort. In order to improve survival and quality of life, the Continuum of Care approach was initiated since pre-pregnancy, pregnancy, childbirth and childbirth, babies, under-five, to adolescents [2].

The Continuum of Care for reproductive, maternal, newborn and child health (RMNCH) includes integrated service delivery for mothers and children from pre-pregnancy to delivery, the immediate postnatal period, and childhood. Such care is provided by families and communities, through outpatient services, clinics and other health facilities. The first dimension of the Continuum of Care is time: from pre-pregnancy, through pregnancy, childbirth, and the early days and years of life, and the second is place: linking the various levels of home, community, and health facilities [1].

In Indonesia, health care in continuum of care policies for pregnant women to childbirth, postpartum and neonatal health, including pregnancy health services, early initiation of breastfeeding, vitamin $\mathrm{K}$ injection, Hepatitis B immunization, postpartum family planning, and Emergency obstetric and newborn care (EmONC). Meanwhile, infant and under-five health care consist of exclusive breastfeeding, complete basic immunization, supplementary feeding, weighing, giving vitamin A and integrated management of sick under-five children [2].

The Ministry of Health establish intervention strategies to reduce maternal and child mortality, consisting of increasing access to universal health services, improving the quality of health services, strengthening governance and community empowerment. Maternal, neonatal, infant and under-five morbidity and mortality are the responsibility of various sectors, requiring cooperation in many sector and support [7]. 


\section{Collaborative Governance}

Ansell and Gash [11] state that collaborative governance as a governance arrangement in which one or more public institutions directly involve non-state stakeholders in a collective decision-making process that is formal, consensus-oriented and deliberative and which aims to make or implementing public policies or administering public programs or assets. This definition emphasizes six important criteria, among others: 1) The forum is initiated by public institutions and actors in public institutions, 2) Participants in the forum include non-state actors; 3) Participants are directly involved in making and decision making and do not have to refer to public actors; 4) Forums are organized formally and meetings are held collectively; 5) Forum aims to make decisions by consensus; 6) The focus of cooperation is public policy or management. Collaborative governance as a process and structure in public management and policy by involving actors from various levels, at the government, private, or civil society levels in order to achieve public goals that cannot be achieved by one party only [12]. Booher and Innes, state that the collaborative governance model requires all stakeholders to be involved in dialogue, where stakeholders represent themselves in expressing their interests [13].

Collaboration is an important element in collaborative governance. The term 'Collaboration' refers to the process of working with others to achieve a common objective or task. It is a method where a greater number of people or organizations are involved to share the responsibilities and achieve the goal. Important stakeholders in advocacy activities are: government, civil society organizations; union federations; business organizations; religious organizations and media [14].

In a collaborative governance model that involves stakeholders, convey the Penta Helix model, consisting of government, business, academia, civil society and media, which is a development from the Triple Helix model which consists of government, business and academia, and the Quadruple Helix (consisting of government, business, academia, and civil society) [15][16].

Advocacy to stakeholders aimed at reducing infant mortality is very important as an effort to increase knowledge and be able to direct behaviour in dealing with risky conditions in maternal pregnancy and childbirth, infant health, thereby reducing the risk of infant mortality [14].

\section{Studies on Collaborative Governance Approaches in Public Policy}

Collaborative Governance in the last two decades has been widely used as an important approach in the process of governance and public policy [11]. Many studies about collaborative governance, and most of the studies show that a collaborative governance approach has positive implications for better results. The examples of several studies on the application of collaborative governance related to public health are as follows.

Astuti and Asmarasari research examines the practice of exclusive breastfeeding, in Semarang City. The results of this study recommend the use of a collaborative governance model in advocating for exclusive breastfeeding, built on Penta Helix stakeholders' charts. This model is presumed to be able to enhance self-efficacy in exclusive breastfeeding based on the actor's role and interest [13].

Frankowski in the Netherlands examines collaborative governance as a policy strategy in health care. The studied policy-based governance mechanisms for the coordination of multiple 
micro-level collaborative initiatives function partly as platforms in bringing actors and resources together successfully. The study applies ideas from public administration to the field of health organization and management to avert failures in the translation of policy ambitions into health practice [17].

Achim Lang examines policy instrument procedures for integrating collaborative governance approaches to health policy and technology in Europe. He had a new policy instrument procedure model, based on the collaborative governance dimension and recommends its implementation [18].

Emerson examines the potentials and challenges of designing and managing cross-sector collaborative governance in the context of public health provision in low and moderate income countries, and recommends the application of collaborative governance based on public administration studies [18].

Fauzi, Yayuk and Fauzi, analyzed the collaborative process of handling HIV/AIDS in DKI Jakarta Province, and provided recommendations for effective collaborative governance in the context of handling HIV/AIDS [19].

\section{Collaborative Governance in Policy Advocacy of Continuum of Care: Penta Helix Stakeholder Model}

In the stakeholder Penta Helix approach [15][16], there are five elements that plays the role in this Collaborative Governance. The expected roles in the continuum of care policy advocacy from the stakeholders are as follows:

\subsection{Government}

Government is the key element. The government element in maternal and child health services includes the central government (the Indonesian Ministry of Health as the leading sector), supported by other relevant ministries and local governments at the provincial and district/city levels. The role of the Indonesian Ministry of Health is as a regulator and harmonizes various programs/activities for the Continuum of Care policy advocacy on maternal health at reproductive age, pregnancy/childbirth, and child health. Other relevant ministries (Social, Education, Home Affairs and other ministries) provide support in the form of policies that are harmonized and synchronized by the Ministry of Health. Local government elements include the provincial government (with provincial health offices), district/city governments (with district/city health offices), also existing service units such as government hospitals, community health center units called Puskesmas, and other health service units in the regions. Local government (Health Office as the leading sector), determines regulations and facilitates policy advocacy of Continuum of care based on higher government regulations adapted to local conditions. Puskesmas, through health workers as the party that interacts directly with the community, has a role in conducting socialization and advocacy, as well as regular monitoring to reach all pregnant and childbirth women, and children in the area. The hospital plays a role in the advocacy and services of pregnant women and childbirth cases served, and children served. The role of government is also important in providing advocacy facilities and infrastructure, as well as facilitating the participation of other stakeholders in advocacy. The government also provides advocacy financing, and provides stimulus to other stakeholders to participate. 


\subsection{Non-Government Organizations/Civil Society}

For over three decades, the United Nations has been issuing declarations that promote civil society and community involvement. Nonetheless, while citizen participation has intensified, in many cases it still does not live up to the spirit of those declarations [20].

The Government of Ghana implement innovative strategies in HIV Care Continuum, including index testing, contact tracing and testing, targeted outreach testing services, and use of case managers to identify, link and support clients to antiretroviral therapy. The civil society organization in this project had involved active in Care Continuum, and improve the capacity of HIV prevention, care and support services [21].

In Indonesia, civil society or non-government organizations (NGOs) in the health sector are expected to actively provide input/suggestions related to the continuum of care, and facilitate advocacy for mother and child services for NGOs that have this program.

Other NGOs that are expected to play a major role are health professional an organization, especially doctors, nurses and midwives' organizations. This professional organization compiles competency standards for health workers who are members in carrying out the profession, including carrying out policy advocacy and implementing the continuum of care, as well as providing advice to the government and other parties related to maternal and child health services.

\subsection{Business/Private}

The role of the private sector in advocating for the continuum of care for infants is divided into private institutions that provide health services (including private organizations, private hospitals, professional practitioners and private clinics), and those that do not provide health services. Private companies (where mothers work, or other labour institutions) are expected to provide support to mothers, including by facilitating advocacy for the continuum of maternal and child health care in the workplace, as well as providing more flexibility for pregnant/postpartum mothers to breastfeed and care for their babies.

In healthcare, the continuum of care is now can be describe in how healthcare providers follow a patient from preventive care, through medical incidents, rehabilitation, and maintenance. Private organizations that provide health services are invited to participate more in advocacy along with the provision of health services that ensure the success of advocacy.

\subsection{Academics}

The elements included in academics are people who have competence in the health sector, both individually and institutionally. The role of academics in efforts to reduce maternal, neonatal, infant and under-five mortality is to be involved in collaboration, especially monitoring and evaluation, research/policy analysis, and providing advice to the government and other parties involved in collaborations related to advocacy and study of the continuum of care.

In Indonesia, there are many higher education institutions with credible experts/academics in surrounding cities, as well as national research institutions, which have the potential to be more involved in advocacy efforts, also providing studies related to maternal and child health efforts. The role of academics is in monitoring and evaluation the implementation of advocacy policy in Continuum of Care, and do the research and policy analysis in the implementation of policy, and with another stakeholder try to make better implementation. 


\subsection{Media}

The high public access to the media makes the role of the media very effective in building understanding among the public about the high risk of pregnancy and childbirth, also children health. The media in this case are newspapers, radio, local TV, and online media. Media advocacy blends communications, science, politics, and advocacy to advance public health goals.

Advocacy and communications are critical to prioritizing policy and financial attention to women's, and children's health; ensuring that all stakeholders have access to the latest evidence; and encouraging stakeholders to play their role in improving health outcomes. Advocacy focused on accountability is also critical to ensuring that commitments are fulfilled and that progress is sustained [22]. The media plays a role in the publication of policies on maternal and child health services, conditions for infant health services and in advocacy materials for policy continuum of care related to efforts to reduce infant mortality.

Table 2. Recommendations for stakeholder collaboration in policy advocacy on the continuum of care

\begin{tabular}{|c|c|}
\hline Stakeholder & Role \\
\hline Government & $\begin{array}{l}\text { a. Making the necessary regulations. } \\
\text { b. Alignment of programs/activities related to the Continuum } \\
\text { of Care with other health services. } \\
\text { c. Financing and providing infrastructure related to infant } \\
\text { health advocacy. } \\
\text { d. Escorting the implementation of regulations. }\end{array}$ \\
\hline $\begin{array}{l}\text { NGO } \\
- \text { NGO in health sector }\end{array}$ & $\begin{array}{l}\text { a. Provide input/suggestions related to the continuum of care. } \\
\text { b. Facilitating advocacy for mother and child services for } \\
\text { NGOs that have the program. }\end{array}$ \\
\hline $\begin{array}{l}\text { - Health professional } \\
\text { organizations }\end{array}$ & $\begin{array}{l}\text { a. Establish competency standards in maternal and infant } \\
\text { health services and disseminate information to members, } \\
\text { supervise members and collaborate on policy advocacy with } \\
\text { other parties. } \\
\text { b. Facilitating advocacy, cross-sector meetings, monitoring } \\
\text { and evaluation. } \\
\text { c. Provide advice to the government and other parties related } \\
\text { to health services. }\end{array}$ \\
\hline Business/Private & $\begin{array}{l}\text { a. Support advocacy development and funding. } \\
\text { b. Facilitating advocacy for the continuum of care for maternal } \\
\text { and infant health in the workplace, as well as providing } \\
\text { more flexibility for pregnant/postpartum mothers to } \\
\text { breastfeed and care for their babies. } \\
\text { c. Health services are followed by advocacy by private } \\
\text { institutional/private practices. }\end{array}$ \\
\hline Academics & $\begin{array}{l}\text { a. Monitoring and evaluation. } \\
\text { b. Research/Policy analysis. }\end{array}$ \\
\hline Media & $\begin{array}{l}\text { a. Build an understanding of the anticipated risks of pregnancy } \\
\text { and childbirth so that mothers and neonates are safe and } \\
\text { healthy, as well as infants and toddlers. }\end{array}$ \\
\hline
\end{tabular}


b. Publication of advocacy and implementation of policies on the Continuum of care in maternal and child health services and reduction of mortality.

There are possible barriers to collaborative governance; Collaborative governance must consider the effects of interactions built up during the collaborative process, such as distrust and interdependence between actors. If one actor threatens to leave the collaboration, the commitments of the other actors can shift, and this will make it difficult to develop a sense of belonging, understanding or trust in the next process. Collaboration can fail if the participation of interest groups and other stakeholders is ignored and unnecessary, so that there is still dominance from one actor to another [11].

Referring to the various statements regarding collaborative governance above, collaboration emerges from the interdependent relationship that exists between parties or between stakeholders with a specific goal of agreement. The government, with the Ministry of Health and the Health Office (in the regions) as the leading sector of health services, must be able to accommodate various other parties, because it has the potential to dominate the decisionmaking process, so it is necessary to develop effective collaborative governance, by facilitating decision making between various stakeholders. Consensus can help balance power between stakeholders. The role of a facilitator or public manager is needed in balancing the power between stakeholders.

\section{Conclusion}

Indonesian Government has to reduce maternal, neonatal, infant and under-five mortality. Ministry of Health adopt Continuum of Care concept in improving Indonesian women's and children's health. Policy advocacy about this concept that involves various stakeholders is the important element.

Stakeholder in the Collaborative Governance approach, consisting of government, business, academia, and civil society (Penta Helix stakeholders' model), potent to increase policy advocacy on the continuum of care. There are opportunities with collaborative governance approach optimally in the Penta Helix stakeholders' model, will support for policy advocacy on continuum of care in improving women's and children's health.

\section{References}

[1] World Health Organization, PMNCH operational principles. The Partnership continues to promote the Continuum of Care, 2020.

[2] Kementerian Kesehatan Republik Indonesia, Perencanaan Terpadu Kesehatan Ibu dan Anak. Jakarta, 2014

[3] J. McCarthy and D. Maine, "A framework for analyzing the determinants of maternal mortality," Stud. Fam. Plann., vol. 23, no. 1, pp. 23-33, 1992.

[4] World Health Organization, Maternal Mortality. 2019.

[5] D. Santoso, “Administrasi Publik," in Sustainable Development Goals (SDG 's), Jakarta: Yayasan Pustaka Obor, 2019

[6] ASEAN Secretariat, ASEAN Statistical Report on Millennium Development Goals. Jakarta, 2017.

[7] Kementerian Kesehatan Republik Indonesia, Strategi Akselerasi Penurunan Angka Kematian Ibu dan Bayi Baru Lahir. Tangerang: Bahan Presentasi Direktur Jenderal Kesehatan Masyarakat: Rapat Kerja Kesehatan Nasional, 2019. 
[8] World Health Organization, Global Health Observatory data: Infant Mortality. 2019.

[9] AIPI, "6 Penyebab kematian ibu melahirkan versi AIPI," AIPI, 2018. [Online]. Available: https://www.cnnindonesia.com/gaya-hidup/20180329175510-255-286923/6-penyebabkematian-ibu-melahirkan-versi-aipi.

[10] Pemerintah Republik Indonesia, Undang-undang Republik Indonesia No. 36 tahun 2009 tentang Kesehatan. 2009.

[11] G. A. Chris A, "Collaborative Governance in Theory and Practice/Ansell Chris, Alison Gash," J. Public Adm. Res. Theory, no. 18, p. 4, 2007.

[12] K. Emerson, T. Nabatchi, and S. Balogh, "An integrative framework for collaborative governance," J. public Adm. Res. theory, vol. 22, no. 1, pp. 1-29, 2012.

[13] R. S. Astuti and B. Asmarasari, "Collaborative Governance in Policy Advocacy of Exclusive Breastfeeding Practice in Semarang City," in Third International Conference on Social Transformation, Community and Sustainable Development (ICSTCSD 2019), 2020, pp. 30-34.

[14] A. Raj, “Advocacy, Collaboration \& Networking," Found. Youth Dev. Rajiv Gandhi Natl. Inst. Youth Dev. Sriperumbudur India, 2016.

[15] A. S. Halibas, R. O. Sibayan, and R. L. R. Maata, "The Penta Helix Model of Innovation In Oman: An HEI Perspective,” Interdiscip. J. Information, Knowl. Manag., vol. 12, 2017.

[16] K. Sudiana, E. T. Sule, I. Soemaryani, and Y. Yunizar, "The development and validation of the penta helix construct," Bus. Theory Pract., vol. 21, no. 1, pp. 136-145, 2020.

[17] A. Frankowski, "Collaborative governance as a policy strategy in healthcare," J. Health Organ. Manag., 2019.

[18] A. Lang, "Collaborative governance in health and technology policy: The use and effects of procedural policy instruments," Adm. Soc., vol. 51, no. 2, pp. 272-298, 2019.

[19] A. R. Fauzi and A. Y. S. Rahayu, "Collaborative Governance Penanganan HIV AIDS di Provinsi DKI Jakarta,” Sawala J. Adm. Negara, vol. 7, no. 1, pp. 1-11, 2019.

[20] Pan American Health Organization, The Role of Civil Society and Community in Health PolicyMaking. 2017.

[21] J. Snow, Ghana Strengthening the Care Continuum (USAID). Inc. JSI PROJECTS, 2019.

[22] World Health Organization, PMNCH Advocacy and Communications Strategy 2016-2018. 2016. 